\title{
ANALISIS FAKTOR YANG MEMPENGARUHI STATUS PENERIMAAN BERAS KELUARGA MISKIN MENGGUNAKAN REGRESI LOGISTIK BINER DI KECAMATAN LANGSA BARAT
}

\section{Analysis of Factors that Affecting the Status of Raskin Acceptance by Using Binary Logistic Regression in Langsa Barat District}

\author{
Amelia $^{1 *}$, Fitra Muliani ${ }^{2}$, Ulya Nabilla ${ }^{3}$ \\ ${ }^{1,2}$ Program Studi Matematika, Fakultas Teknik, Universitas Samudra \\ Meurandeh, Langsa, Aceh, 24416, Indonesia
}

e-mail:1*ameliamath@unsam.ac.id,; 2 fitramuliani@unsam.ac.id; ${ }^{3}$ ulya.nabilla@unsam.ac.id; Corresponding author*

\begin{abstract}
Abstrak
Kemiskinan merupakan ketidakmampuan memenuhi kebutuhan dasar yang diukur berdasarkan pengeluaran, termasuk konsumsi beras. Berdasarkan data dari Badan Pusat Statistik (BPS), sebanyak 95\% dari jumlah penduduk Indonesia mengkonsumsi beras sebagai pangan utama, dengan rata-rata konsumsi beras sebesar $102 \mathrm{~kg} / \mathrm{jiwa} / \mathrm{tahun}$ (BPS, 2013). Lebih lanjut, BPS menyatakan hampir 1/4nya atau sekitar 25,95 juta penduduk tersebut termasuk katagori penduduk miskin per Maret 2018. Sehingga pemerintah membuat kebijakan guna menanggulangi permasalahan tersebut melalui program pemberian Beras Keluarga Miskin (raskin), yaitu bantuan beras bersubsidi kepada rumah tangga miskin. Namun dalam pelaksanaan program raskin, terdapat penyimpangan yaitu sekitar $40 \%$ penduduk Indonesia dengan status sosial ekonomi menengah-atas menerima raskin dan $12,5 \%$ penduduk dengan status sosial ekonomi atas menerima raskin. Oleh karena itu penelitian ini bertujuan menganalisa faktor yang signifikan serta berpengaruh terhadap status penerimaan beras keluarga miskin menggunakan anilisis regresi logistik biner. Lokasi penelitian dilakukan di Kecamatan Langsa Barat karena kecamatan tersebut merupakan salah satu kecamatan penerima raskin terbanyak di Kota Langsa. Data yang digunakan dalam penelitian ini adalah data primer dan data sekunder. Hasil penelitian menunjukkan bahwa faktor yang mempengaruhi status penerimaan Raskin adalah tingkat pendidikan, jenis lantai, jenis bahan bakar, pengeluaran untuk makan, dan frekuensi pembelian baju baru dengan ketetapan klasifikasi prediksi sebesar 72,2 \%.
\end{abstract}

Kata Kunci : Raskin, Regresi Logistik Biner, Kecamatan Langsa Barat.

\begin{abstract}
Poverty is an inability to meet basic needs measured by expenditure, including rice consumption. Based on data from the Central Statistics Agency (BPS), as much as 95\% of Indonesia's population consumes rice as the main food, with an average rice consumption of $102 \mathrm{~kg} /$ person/ year (BPS, 2013). Furthermore, BPS stated that almost 1/4 of them or around 25.95 million people were included in the category of the poor population as of March 2018. So the government made a policy to tackle the problem through the program of giving poor family rice (Raskin), namely subsidized rice assistance to households poor. However, in the implementation of the Raskin program, there was a deviation of around 40\% of Indonesia's population with a middle-upper social-economic status receiving Raskin and $12.5 \%$ of the population with a socio-economic status upon receiving Raskin. Therefore this study aims to analyze the significant factors that affect the status of rice in poor families using binary logistic regression analysis. The location of the study was conducted in the District of West Langsa because the district was one of the districts receiving the most Raskin in the City of Langsa. The data used in this study are primary data and secondary data. The results showed that the factors influencing the status of Raskin's acceptance were education level, floor type, fuel type, food expenses, and frequency of purchasing new clothes with prediction classification prediction of $72.2 \%$.
\end{abstract}

Keywords: Raskin, Binary Logistic Regression, District West Langsa. 


\section{PENDAHULUAN}

Kemiskinan merupakan permasalahan yang masih terjadi hingga saat ini. Masalah kemiskinan masih menjadi permasalahan yang berkepanjangan dan memprihatinkan. Secara umum kemiskinan adalah ketidakmampuan masyarakat dalam memenuhi kebutuhan fisik dasar sebagai manusia. Adapun kebutuhan fisik dasar tersebut adalah kebutuhan akan pangan, sandang, kesehatan, pendidikan, perumahan, air bersih dan sanitasi serta rasa aman [2]. Dua kondisi penyebab kemiskinan terjadi yaitu kemiskinan alamiah dan buatan. Kemiskinan alamiah terjadi antara lain akibat sumber daya alam yang terbatas, penggunaan teknologi yang rendah dan bencana alam. Kemiskinan "buatan" terjadi karena lembaga-lembaga yang ada di masyarakat membuat sebagian anggota masyarakat tidak mampu menguasai sarana ekonomi dan berbagai fasilitas lain yang tersedia, hingga mereka tetap miskin. Maka itulah sebabnya para pakar ekonomi sering mengkritik kebijakan pembangunan yang sering terfokus pada pertumbuhan ketimbang pemerataan [3].

Jumlah penduduk miskin di Indonesia per periode 1999 meningkat dari 13,96 juta menjadi 47,97 juta. Sementara itu, jumlah penduduk miskin pada bulan Maret 2010 (penduduk dengan pengeluaran perkapita perbulan di bawah garis kemiskinan) di Indonesia mencapai 31,01 juta (13,33\%) sedangkan pada Maret 2012 jumlah penduduk miskin di Indonesia mencapai 29,13 juta orang [2]. Lebih lanjut, BPS juga menyatakan sekitar 25,95 juta penduduk tersebut termasuk katagori penduduk miskin per Maret 2018. Besarnya jumlah penduduk miskin akan berdampak pada pemenuhan kebutuhan pangan penduduk yaitu beras.

Penduduk Indonesia adalah konsumen beras terbesar di dunia dengan tingkat konsumsi $154 \mathrm{~kg}$ per orang per tahun (hastina). Hal yang sama diungkapkan oleh Badan Pusat Statistik (BPS) yang menyatakan bahwa sebanyak 95\% dari jumlah penduduk Indonesia mengkonsumsi beras sebagai pangan utama, dengan rata-rata konsumsi beras sebesar $102 \mathrm{~kg} / \mathrm{jiwa} /$ tahun (Di akses dari www.bps.go.id pada tanggal 10 Agustus 2018). Konsumsi beras yang besar di Indonesia harus diimbangi dengan produksi beras sehingga mencukupi kebutuhan nasional.

Untuk menanggulangi hal tersebut, pemerintah membuat suatu program Beras Keluarga Miskin (raskin) yang diperuntukan bagi kalangan penduduk dengan kondisi ekonomi di bawah rata-rata. Raskin berupa bantuan beras bersubsidi kepada rumah tangga miskin (RTM). Suatu rumah tangga dikategorikan RTM berdasarkan karakteristik kemiskinan. Terdapat 14 variabel karakteristik kemiskinan, yaitu status kependudukan, pendidikan terakhir, frekuensi makan, frekuensi pembelian daging, frekuensi pembelian susu, kesanggupan membayar biaya pengobatan, luas lantai, jenis dinding, jenis lantai, sumber penerangan, jenis bahan bakar, fasilitas tempat bab, pengeluaran untuk makanan, dan frekuensi membeli pakaian baru. Jika rumah tangga tersebut memiliki minimal 9 karakteristik kemiskinan maka rumah tangga tersebut dikategorikan RTM dan layak mendapatkan raskin [4].

Menurut pedoman umum [5] keberhasilan raskin diukur berdasarkan tingkat pencapaian indikator 6T, yaitu tepat sasaran penerimaan manfaat, tepat jumlah, tepat waktu, tepat kualitas dan tepat administrasi. Namun pada kenyataannya, terdapat penyimpangan dalam pelaksanaan program raskin di lapangan. Menurut tim TNP2K, sekitar 40\% penduduk Indonesia dengan status sosial ekonomi menengah-atas menerima raskin dan $12,5 \%$ penduduk dengan status sosial ekonomi atas menerima raskin. Hal ini menunjukkan tidak tepat sasaran penerimaan raskin. Penelitian sebelumnya tentang raskin [6], [7] dan beberapa penelitian sebelumnya tentang analisis regresi logistik [8]-[11] tapi bukan pada raskin. Oleh karena itu, yang menjadi permasalahan disini yaitu bagaimana mengetahui faktor yang berpengaruh signifikan terhadap status penerimaan beras keluarga miskin di Kecamatan Langsa Barat.

Metode regresi logistik biner tersebut merupakan suatu metode analisis data yang untuk mencari hubungan antara variabel respon (y) yang bersifat biner dengan variabel prediktor $(x)$ [12]. Pada penelitian ini variabel respon $y$ adalah status penerimaan raskin dan variabel prediktor $x$ variabel adalah karakteristik kemiskinan. Variabel respon terdiri dari dua kategori yaitu terima yang dinotasikan dengan $y=1$ dan tidak terima yang dinotasikan dengan $y=0$.

\section{METODE PENELITIAN}

Lokasi penelitian dilakukan di Kecamatan Langsa Barat Kota Langsa Provinsi Aceh, karena kecamatan tersebut merupakan penerima raskin terbanyak di Kota Langsa dengan jumlah sampel sebanyak 212 responden. Penelitian dilaksanakan pada tanggal 02 April - 29 Juni 2019. Variabel yang digunakan adalah 
variabel respon $(Y)$ dan variabel prediktor $(X)$. Variabel respon merupakan status RTM penerima raskin dan variabel prediktor adalah karakteristik kemiskinan (Tabel 1).

Tabel 1.Variabel Respon dan Prediktor

\begin{tabular}{|c|c|c|c|}
\hline No. & $\begin{array}{c}\text { Jenis } \\
\text { Variabel }\end{array}$ & Karaktei & istik kemiskinan \\
\hline 1 & $Y$ & Status penerima raskin & $\boldsymbol{Y}=\left\{\begin{array}{cc}0, \text { tidak menerima raskin } \\
1, \quad \text { menerima raskin }\end{array}\right.$ \\
\hline 2 & $X_{1}$ & Pendidikan terakhir & $\boldsymbol{X}_{\mathbf{1}}=\left\{\begin{array}{l}0, \text { SMA } / \text { Perguruan ting gi } \\
1, \text { tidak sekolah } / S D / S M P\end{array}\right.$ \\
\hline 3 & $X_{2}$ & $\begin{array}{l}\text { Pembelian daging dalam seminggu } \\
\text { terakhir }\end{array}$ & $\boldsymbol{X}_{2}=\left\{\begin{array}{c}0, \text { membeli } \\
1, \text { tidak membeli }\end{array}\right.$ \\
\hline 4 & $X_{3}$ & $\begin{array}{l}\text { Kesanggupan membayar } \\
\text { biaya pengobatan }\end{array}$ & $\boldsymbol{X}_{\mathbf{3}}=\left\{\begin{array}{c}0, \text { sanggup } \\
1, \text { tidak sanggup }\end{array}\right.$ \\
\hline 5 & $X_{4}$ & $\begin{array}{l}\text { Luas lantai bangunan } \\
\text { tempat tinggal }\end{array}$ & $\boldsymbol{X}_{4}=\left\{\begin{array}{l}0,>8 m^{2} \text { per orang } \\
1, \leq 8 m^{2} \text { per orang }\end{array}\right.$ \\
\hline 6 & $X_{5}$ & $\begin{array}{l}\text { Jenis dinding bangunan } \\
\text { tempat tinggal }\end{array}$ & $\boldsymbol{X}_{\mathbf{5}}=\left\{\begin{array}{c}0, \text { tembok } \\
1, \text { bukan tembok }\end{array}\right.$ \\
\hline 7 & $X_{6}$ & $\begin{array}{l}\text { Jenis lantai bangunan } \\
\text { tempat tinggal }\end{array}$ & $\boldsymbol{X}_{\mathbf{6}}=\left\{\begin{array}{c}0, \text { bukan tanah } \\
1, \text { tanah }\end{array}\right.$ \\
\hline 8 & $X_{7}$ & $\underset{\backslash}{\text { Jenis sumber penerangan utama }}$ & $\boldsymbol{X}_{7}=\left\{\begin{array}{c}0, P L N \\
1, \text { bukan PLN }\end{array}\right.$ \\
\hline 9 & $X_{8}$ & Jenis bahan bakar & $\boldsymbol{X}_{\mathbf{8}}=\left\{\begin{array}{c}0, \text { gas } \\
1, \text { bukan gas }\end{array}\right.$ \\
\hline 10 & $X_{9}$ & fasilitas tempat $B A B$ & $\boldsymbol{X}_{\mathbf{9}}=\left\{\begin{array}{c}0, \text { milik pribadi } \\
1, \text { bukan milik pribadi }\end{array}\right.$ \\
\hline 11 & $X_{10}$ & $\begin{array}{l}\text { Pengeluaran untuk makanan } \\
\text { dalam sebulan }\end{array}$ & $\boldsymbol{X}_{\mathbf{1 0}}=\left\{\begin{array}{c}0, \text { lebih dari } R p 700.000,00 \\
1, \text { kurang dari atau sama } \\
\text { dengan } R p \text { 700.000,00 }\end{array}\right.$ \\
\hline 12 & $X_{11}$ & $\begin{array}{l}\text { Frekuensi membeli pakaian baru } \\
\text { dalam setahun }\end{array}$ & $\boldsymbol{X}_{\mathbf{1 1}}=\left\{\begin{array}{c}0,1 \text { kali } \\
1, \text { lebih dari } 1 \text { kali }\end{array}\right.$ \\
\hline 13 & $X_{12}$ & $\begin{array}{l}\text { Frekuensi membeli susu dalam } \\
\text { seminggu terakhir }\end{array}$ & $\boldsymbol{X}_{\mathbf{1 2}}=\left\{\begin{array}{c}0, \text { membeli } \\
1, \text { tidak membeli }\end{array}\right.$ \\
\hline
\end{tabular}

Data yang digunakan adalah data primer yang diperoleh dari kueasioner dan data sekunder yang diperoleh. dari kantor Kecamatan Langsa barat.

Penelitian dilakukan melalui beberapa tahap, yaitu:

a. Menyusun data berdasarkan karakteristik kemiskinan. Hal ini bertujuan untuk memperoleh data yang bersifat kategorikal dari setiap variabel prediktor.

b. Menganalisis data secara statistik deskriptif.

c. Melakukan penaksiran parameter menggunakan metode estimasi maximum likelihood. Nilai parameter yang dipilih adalah nilai parameter yang memaksimalkan nilai fungsi likelihood. Untuk menentukan nilai estimasi parameter dari model, akan digunakan software SPSS.

d. Melakukan uji signifikansi parameter secara parsial dan serentak untuk setiap variabel prediktor.

e. Memilih model terbaik berdasarkan variabel prediktor yang berpengaruh secara signifikan terhadap variabel respon.

f. Melakukan uji kecocokan model

g. Interpretasi parameter logistik

h. Kesimpulan

\section{HASIL DAN PEMBAHASAN}

\subsection{Eksplorasi Data}

Data yang diperoleh dari kuesioner, diasumsikan mengikuti regresi logistik biner. Kemudian data tersebut disajikan dalam Tabel 2. 
Tabel 2. Data Penelitian

\begin{tabular}{|cccccc|}
\hline No & $\mathrm{Y}$ & $\mathrm{X}_{1}$ & $\mathrm{X}_{2}$ & $\cdots$ & $\mathrm{X}_{12}$ \\
\hline 1 & 1 & 1 & 1 & $\cdots$ & 1 \\
2 & 1 & 1 & 1 & $\cdots$ & 1 \\
3 & 1 & 1 & 1 & $\cdots$ & 1 \\
$\cdots$ & $\cdots$ & $\cdots$ & $\cdots$ & $\cdots$ & $\cdots$ \\
212 & 0 & 1 & 1 & 0 & 1 \\
\hline
\end{tabular}

\subsection{Analisis Statistik Deskriptif dari Data}

Statistik deskriptif menggunakan persentase untuk masing-masing variabel. Namun pada penulisan ini, hanya ditampilkan persentase dari variabel yang berpengaruh secara signifikan. Berdasarkan hasil analisis secara deskriptif diperoleh bahwa dari 210 sampel warga Kecamatan Langsa Barat, terdapat 41,98\% menerima raskin, sedangkan sisanya yaitu 58,02\% tidak menerima raskin. Persentase tersebut disajikan pada Gambar 1.

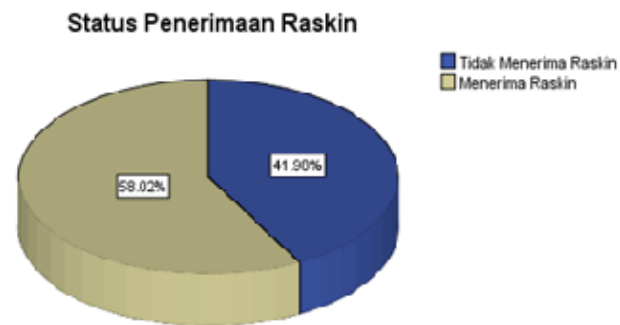

\section{Gambar 1. Status Penerima Raskin}

Jika ditinjau dari faktor pendidikan terakhir yang ditempuh oleh 210 sampel tersebut, hanya 29,72\% yang menempuh pendidikan hingga SMA atau Perguruan Tinggi, sedangkan 70,28\% tidak sekolah atau hanya mampu menempuh hingga tingkat SD atau SMP. Persentase tersebut disajikan pada Gambar 2.

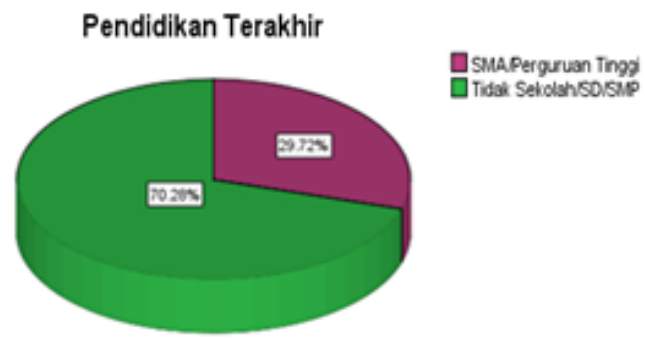

\section{Gambar 2. Status Pendidikan Terakhir}

Jika ditinjau dari faktor jenis lantai bangunan yang menjadi tempat tinggal, sebanyak 85,85\% memiliki bangunan tempat tinggal, tetapi bukan dengan tanah sebagai lantainya, sedangkan $14,15 \%$ dari sampel tersebut memiliki bangunan tempat tinggal dengan tanah sebagai lantainya. Persentase tersebut disajikan pada Gambar 3.

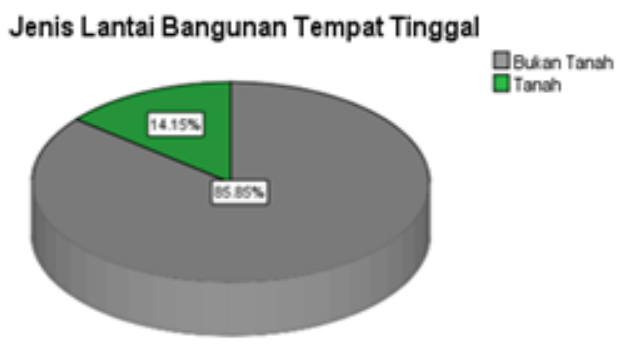

Gambar 3. Jenis Lantai Bangunan Tempat Tinggal 
Jika ditinjau dari faktor jenis bahan bakar, sebanyak $91,04 \%$ dari sampel tersebut menggunakan gas sebagai bahan bakar, sedangkan $8,96 \%$ tidak menggunakan gas sebagai bahan bakar. Persentase tersebut disajikan pada Gambar 4.

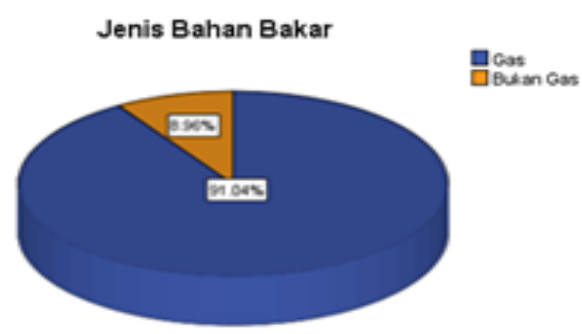

\section{Gambar 4. Jenis Bahan Bakar}

Jika ditinjau dari faktor pengeluaran untuk makanan, sebanyak 79,72\% dari sampel tersebut memiliki pengeluaran makanan sebesar Rp 700.000,00 atau lebih dalam sebulan, sedangkan 20,28\% memiliki pengeluaran makanan kurang dari Rp 700.000,00 dalam sebulan. Persentase tersebut disajikan pada Gambar 5 .

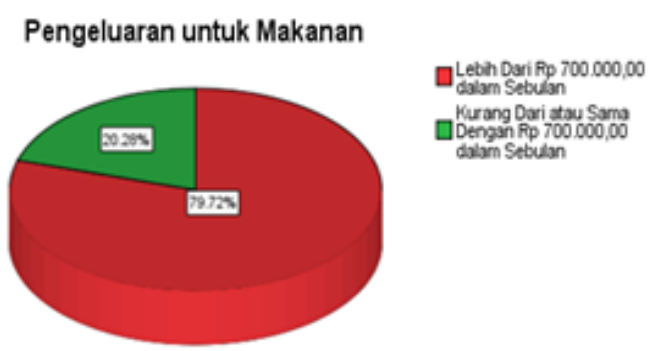

\section{Gambar 5. Pengeluaran untuk Makanan}

Jika ditinjau dari faktor frekuensi membeli pakaian baru, sebanyak 60,85\% dari sampel tersebut hanya satu kali membeli pakaian pakaian baru dalam setahun, sedangkan 39,15\% membeli pakaian pakaian baru dalam setahun lebih dari satu kali. Persentase tersebut disajikan pada Gambar 6.

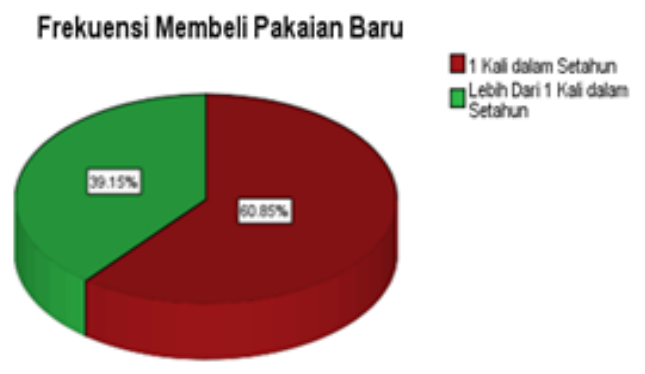

Gambar 6. Frekuensi Membeli Pakaian Baru

Jika ditinjau dari faktor sumber penerangan utama, sebanyak 97,64\% dari sampel tersebut menggunakan PLN sebagai sumber penerangan utama, sedangkan 2,36\% tidak menggunakan PLN sebagai sumber penerangan utama. Persentase tersebut disajikan pada Gambar 7.

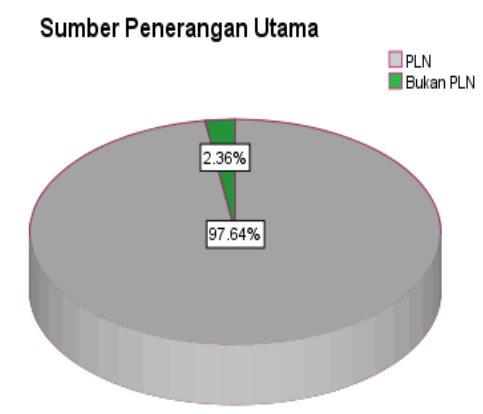

Gambar 7. Jenis Sumber Penerangan Utama 
Jika ditinjau dari faktor jenis bahan bakar, sebanyak 91,04\% dari sampel tersebut menggunakan gas sebagai bahan bakar, sedangkan $8,96 \%$ tidak menggunakan gas sebagai bahan bakar. Persentase tersebut disajikan pada Gambar 8 .

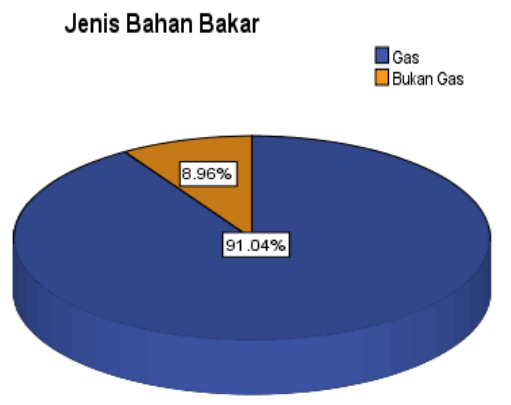

Gambar 8. Jenis Bahan Bakar

Jika ditinjau dari faktor fasilitas tempat $\mathrm{BAB}$, sebanyak 91,98\% dari sampel tersebut memiliki fasilitas tempat $\mathrm{BAB}$ pribadi, sedangkan $8,02 \%$ tidak memiliki fasilitas tempat $\mathrm{BAB}$ pribadi. Persentase tersebut disajikan pada Gambar 9.

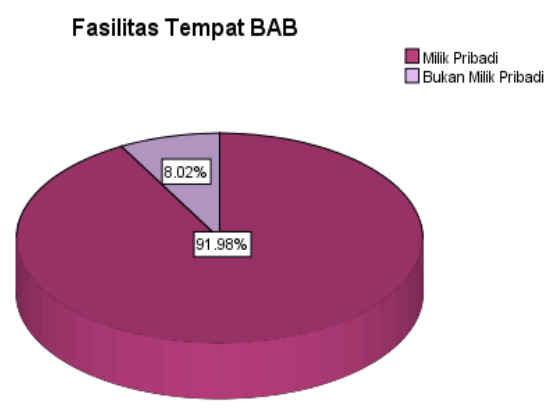

\section{Gambar 9. Fasilitas Tempat BAB}

Jika ditinjau dari faktor pengeluaran untuk makanan, sebanyak 79,72\% dari sampel tersebut memiliki pengeluaran makanan sebesar Rp 700.000,00 atau lebih dalam sebulan, sedangkan 20,28\% memiliki pengeluaran makanan kurang dari Rp 700.000,00 dalam sebulan. Persentase tersebut disajikan pada Gambar 10.

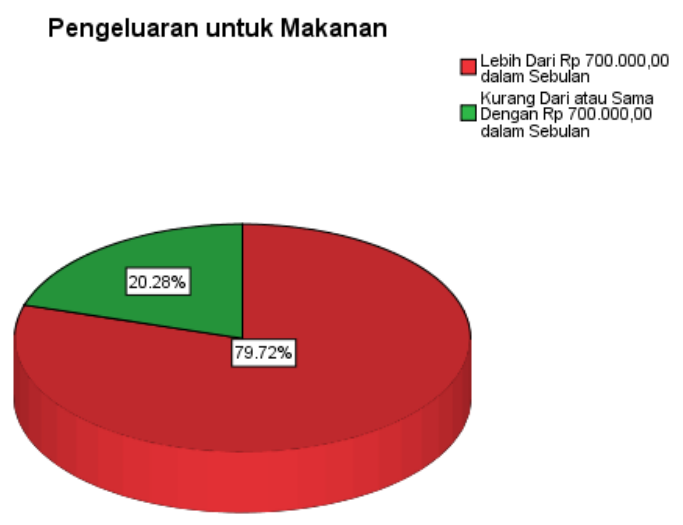

Gambar 10. Pengeluaran untuk Makanan

Jika ditinjau dari faktor frekuensi membeli pakaian baru, sebanyak $60,85 \%$ dari sampel tersebut hanya satu kali membeli pakaian pakaian baru dalam setahun, sedangkan 39,15\% membeli pakaian pakaian baru dalam setahun lebih dari satu kali. Persentase tersebut disajikan pada Gambar 11. 


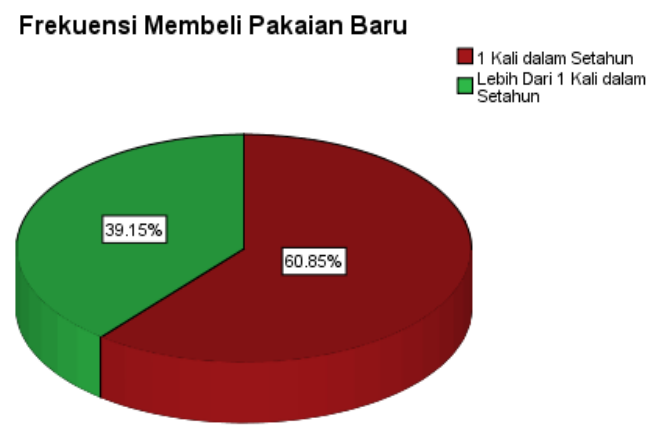

\section{Gambar 11. Frekuensi Membeli Pakaian Baru}

Jika ditinjau dari faktor pembelian susu, sebanyak $81,60 \%$ dari sampel tersebut tidak membeli susu dalam seminggu terkahir ketika pengambilan data ini dilakukan, sedangkan 18,40\% membeli susu dalam seminggu terakhir. Persentase tersebut disajikan pada Gambar 12.

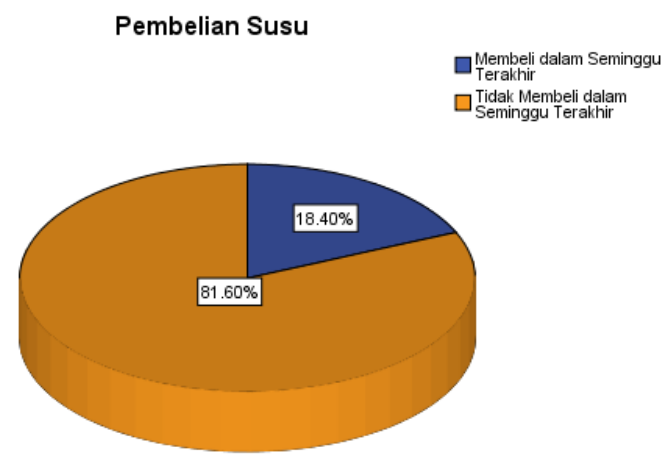

Gambar 12. Pembelian Susu

\subsection{Pemodelan Regresi Logistik}

Regresi logistik merupakan suatu metode analisis statistika yang digunakan untuk mendeskripsikan hubungan antara variabel respon yang memiliki dua kategori atau lebih dengan satu atau lebih peubah berskala kategori [12]. Regresi logistik dapat dibagi menjadi regresi logistik biner, regresi logistik multinomial, dan regresi logistik ordinal. Model regresi logistik biner digunakan untuk data yang bersifat biner atau dikotomus yaitu masing-masing pengamatan pada objek dikelompokkan sebagai "gagal" atau "sukses" yang dinotasikan 1 atau 0 sehingga mengikuti distribusi Bernouli sebagai berikut[13]:

$$
f\left(y_{i}, \pi_{i}\right)=\pi_{i}^{y}\left(1-\pi_{i}\right)^{1-y_{i}} \text {, dengan } y=0,1
$$

dengan, $\pi_{i}$ adalah peluang kejadian ke- i dan $y_{i}$ peubah acak ke-1 yang terdiri dari 0 dan 1 . Untuk model regresi logistik untuk $p$ variabel adalah

$$
\pi(\boldsymbol{X})=\frac{\exp \left(\beta_{0}+\beta_{1} x_{1}+\cdots+\beta_{p} x_{p}\right)}{1+\exp \left(\beta_{0}+\beta_{1} x_{1}+\cdots+\beta_{p} x_{p}\right)}
$$

Untuk mempermudah menaksir parameter regresi, maka persamaan diatas ditransformasikan sehingga menghasilkan bentuk logit regresi logistik sebagai berikut:

$$
g(X)=\ln \left(\frac{\pi(x)}{1-\pi(x)}\right)=\beta_{0}+\beta_{1} x_{1}+\cdots+\beta_{p} x_{p}
$$

Model regresi logistik biner diperoleh dengan melakukan beberapa uji pada variabel prediktor. Uji tersebut dilakukan untuk menganalisis faktor-faktor yang berpengaruh secara signifikan terhadap variabel respon. Ada dua jenis pengujian yang dilakukan, yaitu uji signifikansi parsial dan uji signifikansi serentak. a. Uji Signifikansi Secara Parsial

Uji signifikansi secara parsial dilakukan untuk melihat masing-masing faktor yang berpengaruh signifikan terhadap variabel respon. Hasil pengujian secara individual akan menunjukkan suatu variabel prediktor layak pada suatu model. Uji ini menggunakan statistik uji Wald seperti pada Persamaan (4). 


$$
W=\frac{\widehat{\beta}_{j}}{\operatorname{SE}\left(\widehat{\beta}_{j}\right)}
$$

dengan hipotesis yang digunakan adalah seperti pada Persamaan (5).

$$
\begin{aligned}
& H_{0}: \beta_{k}=0 \\
& H_{1}: \beta_{k} \neq 0, \text { dengan } k=0,1, \ldots, p
\end{aligned}
$$

Indikator penilaian dilihat dari nilai $p$-value. Jika $p$-value $<0,25$ maka variabel tersebut berpengaruh signifikan. Hasil yang diperoleh disajikan dalam Tabel 3:

Tabel 3. Nilai Uji Signifikansi Parsial

\begin{tabular}{|llc|}
\hline \multicolumn{1}{c}{ Variabel } & $\boldsymbol{p}$ & Keterangan \\
\hline Pendidikan terakhir $\left(\mathrm{X}_{1}\right)$ & 0,10 & Berpengaruh \\
Pembelian daging $\left(\mathrm{X}_{2}\right)$ & 0,659 & Tidak berpengaruh \\
Kesanggupan membayar biaya pengobatan $\left(\mathrm{X}_{3}\right)$ & 0,308 & Tidak berpengaruh \\
Luas lantai $\left(\mathrm{X}_{4}\right)$ & 0,179 & Berpengaruh \\
Jenis dinding $\left(\mathrm{X}_{5}\right)$ & 0,687 & Tidak berpengaruh \\
Jenis lantai $\left(\mathrm{X}_{6}\right)$ & 0,021 & Berpengaruh \\
Sumber penerangan $\left(\mathrm{X}_{7}\right)$ & 0,292 & Tidak berpengaruh \\
Jenis bahan bakar $\left(\mathrm{X}_{8}\right)$ & 0,328 & Tidak berpengaruh \\
Fasilitas tempat bab $\left(\mathrm{X}_{9}\right)$ & 0,265 & Tidak berpengaruh \\
Pengeluaran untuk makanan $\left(\mathrm{X}_{10}\right)$ & 0,089 & Berpengaruh \\
Frekuensi membeli pakaian baru $\left(\mathrm{X}_{11}\right)$ & 0,000 & Berpengaruh \\
Pembelian susu $\left(\mathrm{X}_{12}\right)$ & 0,347 & Tidak berpengaruh \\
\hline
\end{tabular}

Dari Tabel 3 dapat dilihat bahwa variabel yang berpengaruh signifikan terhadap penerimaan raskin adalah pendidikan terakhir, luas lantai, jenis lantai, pengeluaran untuk makanan, serta frekuensi membeli pakaian baru. Sedangkan variabel prediktor lainnya tidak berpengaruh secara signifikan terhadap status penerimaan raskin.

b. Uji Signifikansi Secara Serentak

Pengujian signifikansi secara serentak dilakukan untuk memeriksa keterkaitan hubungan yang signifikan antara variabel respon dengan variabel prediktor. Uji ini dilakukan untuk mengetahui signifikansi parameter $\beta_{k}$ terhadap variabel respon secara keseluruhan. Pengujian tersebut menggunakan statistik uji $G$ yang mengikuti distribusi Chi-Square. Berikut ini statistik uji $G$ yang digunakan seperti yang tertera pada Persamaan (6).

$$
G=-2 \ln \frac{\left(\frac{n_{1}}{n}\right)^{n_{i}}\left(\frac{n_{0}}{n}\right)^{n_{0}}}{\sum_{i=1}^{n} \widehat{\pi}_{l}^{y_{i}}\left(1-\widehat{\pi}_{l}\right)^{\left(1-y_{i}\right)}}
$$

dengan daerah penolakannya $G>X^{2}(v, \alpha)$ dan hipotesisnya dinyatakan dalam Persamaan (7)

$H_{0}: \beta_{0}=\beta_{1}=\cdots=\beta_{p}=0$

$H_{1}$ : paling sedikit ada satu $\beta_{k} \neq 0$, dengan $k=0,1, \ldots, p$

Hasil pengujian tersebut dapat dilihat pada Tabel 4:

Tabel 4. Omnibus Test of Model Coefficients

\begin{tabular}{|lcccc|}
\hline & & Chi-square & df & Sig. \\
\hline \multirow{3}{*}{ Step 1 } & Step & 67,379 & 12 & 0,000 \\
\cline { 2 - 5 } & Block & 67,379 & 12 & 0,000 \\
\cline { 2 - 5 } & Model & 67,379 & 12 & 0,000 \\
\hline
\end{tabular}

Berdasarkan Tabel 4 dapat dilihat bahwa nilai chi-square yang diperoleh adalah 67,379, derajat kebebasan 12, dan nilai $p=0,000$. Karena nilai $p<0,05$ maka dapat disimpulkan bahwa variabel prediktor secara serentak berpengaruh signifikan terhadap variabel respon, yaitu status penerimaan raskin.

Selanjutnya dilakukan pengujian model summary untuk mengetahui persentase variabel prediktor berpengaruh terhadap variabel respon. Hasil pengujian tersebut dapat dilihat pada Tabel 5. 
Tabel 5. Model Summary

\begin{tabular}{|cccc|}
\hline Step & $\begin{array}{c}\mathbf{- 2} \text { Log } \\
\text { likelihood }\end{array}$ & $\begin{array}{c}\text { Cox \& Snell } \\
\text { R Square }\end{array}$ & $\begin{array}{c}\text { Nagelkerke } \\
\text { R Square }\end{array}$ \\
\hline 1 & 221,039 & 0,272 & 0,366 \\
\hline
\end{tabular}

Pada Tabel 5, diperoleh nilai $\mathrm{G}$ adalah 221,039 dan nilai nagelkerke $R$ square adalah 0,366. Hal tersebut menyatakan bahwa variabel prediktor mampu menjelaskan sebesar 36,6\% terhadap variabel respon dan sisanya dijelaskan oleh faktor lain. Kemudian dilakukan pengujian signifikansi variabel predictor secara serentak terhadap status penerimaan Raskin. Hasil pengujian tersebut dapat dilihat pada Tabel 6.

Tabel 6. Nilai Uji Signifikansi Secara Serentak

\begin{tabular}{|ccccc|}
\hline Variabel & B & Sig & Exp B & Keterangan \\
\hline $\mathrm{X}_{1}$ &, 962 & 0,013 & 2,618 & Berpengaruh \\
$\mathrm{X}_{2}$ &,- 647 & 0,533 & 0,524 & Tidak Berpengaruh \\
$\mathrm{X}_{3}$ &,- 476 & 0,332 & 0,621 & Tidak Berpengaruh \\
$\mathrm{X}_{4}$ &, 476 & 0,202 & 1,610 & Tidak Berpengaruh \\
$\mathrm{X}_{5}$ &,- 660 & 0,117 & 0,517 & Tidak Berpengaruh \\
$\mathrm{X}_{6}$ & 1,064 & 0,059 & 2,899 & Berpengaruh \\
$\mathrm{X}_{7}$ &, 787 & 0,550 & 2,196 & Tidak Berpengaruh \\
$\mathrm{X}_{8}$ & $-1,446$ & 0,014 & 0,236 & Berpengaruh \\
$\mathrm{X}_{9}$ & 1,149 & 0,117 & 3,154 & Tidak Berpengaruh \\
$\mathrm{X}_{10}$ & 1,312 & 0,012 & 3,713 & Berpengaruh \\
$\mathrm{X}_{11}$ & $-3,000$ & 0,000 & 0,050 & Berpengaruh \\
$\mathrm{X}_{12}$ &,- 022 & 0,960 & 0,978 & Tidak Berpengaruh \\
Constant & 1,793 & 0,108 & 6,009 & Tidak Berpengaruh \\
\hline
\end{tabular}

Berdasarkan Tabel 6, diketahui bahwa terdapat lima variabel prediktor yang memiliki nilai signifikansi dibawah 0,10 yaitu pendidikan terakhir, jenis lantai, jenis bahan bakar, pengeluaran untuk makanan, dan frekuensi membeli pakaian baru. Hal ini menunjukkan bahwa kelima variabel prediktor tersebut berpengaruh secara signifikan terhadap variabel respon.

\subsection{Pemilihan Model Terbaik}

Model terbaik diperoleh dengan mengikutsertakan variabel-variabel prediktor yang berpengaruh secara signifikan. Variabel prediktor yang berpengaruh signifikan terhadap status penerimaan raskin dan menjadi model terbaik dapat dilihat pada Tabel 7:

Tabel 7. Pemilihan Model Terbaik

\begin{tabular}{|ccccl|}
\hline Variabel & B & Sig & Exp B & Keterangan \\
$\mathrm{X}_{1}$ & 0.796 & 0,025 & 2,218 & Berpengaruh \\
$\mathrm{X}_{6}$ & 1,023 & 0,050 & 2,782 & Berpengaruh \\
$\mathrm{X}_{8}$ & $-1,435$ & 0,009 & 0,238 & Berpengaruh \\
$\mathrm{X}_{10}$ & 1,135 & 0,024 & 3,110 & Berpengaruh \\
$\mathrm{X}_{11}$ & $-2,575$ & 0,000 & 0,076 & Berpengaruh \\
Constant & 0,584 & 0,065 & 1,792 & Berpengaruh \\
\hline
\end{tabular}

Tabel 7 menunjukkan terdapat lima variabel yang berpengaruh secara signifikan yaitu pendidikan terakhir, jenis lantai, jenis bahan bakar, pengeluaran untuk makanan, dan frekuensi membeli pakaian baru, dengan nilai signifikan kurang dari 0,10 . Adapun model regresi logistik yang diperoleh adalah seperti pada Persamaan (1):

$$
\hat{\pi}(x)=\frac{\exp \left(0,584+0,796 X_{1}+1,023 X_{6}-1,435 X_{8}+1,135 X_{10}-2,575 X_{11}\right)}{1+\exp \left(0,584+0,796 X_{1}+1,023 X_{6}-1,435 X_{8}+1,135 X_{10}-2,575 X_{11}\right)}
$$

Selain itu, Tabel 7 menunjukkan nilai odd ratio untuk pendidikan terakhir adalah 2,218. Maksudnya adalah kecenderungan rumah tangga yang kepala kelurganya memiliki latar belakang pendidikan tidak sekolah, SD atau SMP berpotensi menerima raskin 2,218 kali dari rumah tangga yang kepala keluarganya memiliki tingkat pendidikan SMA atau Perguruan Tinggi. Untuk jenis lantai, nilai odd rationya 2,782 yang artinya rumah tangga yang berjenis lantai tanah akan berpotensi menerima raskin 2,782 kali dibandingkan rumah tangga yang berjenis lantai rumah bukan tanah. Sementara itu, nilai odd ratio pada pengeluaran untuk 
makanan adalah 3,110 yang berarti bahwa rumah tangga yang memiliki pengeluaran untuk makan kurang dari Rp 700.000,00 perbulan akan berpotensi menerima raskin 3,110 kali dibandingkan rumah tangga yang memiliki pengeluaran makanan lebih dari Rp 700.00,000 per bulan.

\subsection{Interpretasi Nilai Peluang}

Hasil interpretasi nilai peluang dari model regresi logistik biner yang telah diperoleh sebelumnya, dapat dilihat pada Tabel 8:

Tabel 8. Interpretasi Nilai Peluang

\begin{tabular}{|c|c|c|c|c|c|c|c|c|c|c|c|c|}
\hline \multirow{2}{*}{ Variabel } & \multicolumn{12}{|c|}{ Responden } \\
\hline & $\mathbf{R}_{1}$ & $\mathbf{R}_{2}$ & $\mathbf{R}_{3}$ & $\mathbf{R}_{4}$ & $\mathbf{R}_{5}$ & $\mathbf{R}_{6}$ & $\mathbf{R}_{7}$ & $\mathbf{R}_{8}$ & R9 & $\mathbf{R}_{10}$ & $\mathbf{R}_{11}$ & $\mathbf{R}_{12}$ \\
\hline $\mathrm{X}_{1}$ & 1 & 1 & 1 & 1 & 1 & 0 & 1 & 0 & 0 & 0 & 0 & 0 \\
\hline $\mathrm{X}_{6}$ & 1 & 1 & 1 & 1 & 0 & 1 & 0 & 1 & 0 & 0 & 0 & 0 \\
\hline $\mathrm{X}_{8}$ & 1 & 1 & 1 & 0 & 1 & 1 & 0 & 0 & 1 & 0 & 0 & 0 \\
\hline $\mathrm{X}_{10}$ & 1 & 1 & 0 & 1 & 1 & 1 & 0 & 0 & 0 & 1 & 0 & 0 \\
\hline $\mathrm{X}_{11}$ & 1 & 0 & 1 & 1 & 1 & 1 & 0 & 0 & 0 & 0 & 1 & 0 \\
\hline$\hat{\pi}(x)$ & 0,40 & 0,89 & 0,39 & 0,70 & 0,72 & 0,17 & 0,22 & 0,83 & 0,30 & 0,84 & 0,12 & 0,64 \\
\hline
\end{tabular}

Tabel 8 menjelaskan nilai peluang suatu rumah tangga dengan berbagai kategori menerima raskin dan tidak menerima raskin. Sebagai contoh, dapat dijelaskan bahwa rumah tangga yang kepala keluarganya memiliki pendidikan terakhir tidak sekolah/SD/SMP, memiliki jenis lantai rumah tanah, memiliki jenis bahan bakar bukan gas, pengeluaran untuk makan kurang dari 700.000 per bulan dan frekuensi membeli pakaian baru hanya 1 kali dalam setahun akan berpeluang menerima raskin sebesar 0,89 dan memiliki peluang tidak menerima raskin 0,11 .

\subsection{Uji Kecocokan dan Kesesuaian Model}

Selanjutnya dilakukan uji kecocockan model menggunakan Uji Hosmer dan Lemeshow. Hasil pengujian tersebut disajikan pada Tabel 9.

Tabel 9. Uji Hosmer dan Lemeshow

\begin{tabular}{|cccc|}
\hline Step & Chi-square & df & Sig. \\
\hline 1 & 1,197 & 6 &, 977 \\
\hline
\end{tabular}

Berdasarkan Tabel 9, nilai $p=0,977$, nilai $\mathrm{p}>0,05$ dengan nilai chi-square sebesar 1,197. Hal tersebut menunjukkan bahwa model yang dibentuk sesuai atau cocok dengan nilai observasinya. Dengan demikian dapat disimpulkan bahwa pendidikan terakhir, jenis lantai, jenis bahan bakar, pengeluaran untuk makanan, dan frekuensi membeli pakaian baru memberikan kontribusi signifikan terhadap status penerimaan raskin. Sehingga model yang diperoleh, layak untuk memprediksikan peluang penerimaan raskin di Kecamatan Langsa Barat.

\subsection{Klasifikasi Model}

Tahap akhir adalah memprediksi ketepatan model yang telah diperoleh sebelumnya. Hasil prediksi tersebut ditampilkan pada Tabel 10.

Tabel 10. Klasifikasi Model

\begin{tabular}{|ccccc|}
\hline & & \multicolumn{3}{c|}{ Predicted } \\
\cline { 3 - 5 } & & \multicolumn{2}{c|}{ Status Penerima Raskin } & $\begin{array}{c}\text { Percentage } \\
\text { Correct }\end{array}$ \\
\cline { 3 - 5 } & & $\begin{array}{c}\text { Tidak terima } \\
\text { raskin }\end{array}$ & Terima raskin \\
Status & Tidak terima raskin & 60 & 29 & 67,4 \\
$\begin{array}{c}\text { Penerima } \\
\text { Raskin }\end{array}$ & Terima raskin & 30 & 93 & 75,6 \\
& \multicolumn{2}{r}{$\begin{array}{c}\text { Overall } \\
\text { Percentage }\end{array}$} & & 72,2 \\
\hline
\end{tabular}

Persentase pada Tabel 10 adalah 72,2. Hal ini menunjukkan bahwa tingkat pendidikan terakhir, jenis lantai rumah tangga, jenis bahan bakar yang digunakan, pengeluaran untuk makan dan frekuensi membeli pakaian baru memiliki ketepatan untuk memprediksi penerimaan raskin sebesar 72,2\%. 


\section{KESIMPULAN}

Berdasarkan hasil pengolahan data dan pembahasan diperoleh beberapa kesimpulan antara lain sebagai berikut.

1. Faktor-faktor yang mempengaruhi status penerimaan raskin di Kecamatan Langsa Barat adalah Pendidikan terakhir $\left(\mathrm{X}_{1}\right)$, Jenis lantai $\left(\mathrm{X}_{6}\right)$, Jenis bahan bakar $\left(\mathrm{X}_{8}\right)$, Pengeluaran untuk makanan $\left(\mathrm{X}_{10}\right)$, dan Frekuensi membeli pakaian baru $\left(\mathrm{X}_{11}\right)$. Adapun model persamaan atau model regresi logistik yang terbentuk yaitu:

$$
\hat{\pi}(x)=\frac{\exp \left(0,584+0,796 X_{1}+1,023 X_{6}-1,435 X_{8}+1,135 X_{10}-2,575 X_{11}\right)}{1+\exp \left(0,584+0,796 X_{1}+1,023 X_{6}-1,435 X_{8}+1,135 X_{10}-2,575 X_{11}\right)}
$$

Model tersebut memiliki tingkat ketepatan klasifikasi model untuk memprediksi status penerimaan raskin sebesar $72,2 \%$.

2. Dari hasil odd ratio pada setiap variabel dapat dijelaskan bahwa untuk variabel $\mathrm{X}_{1}$ yaitu 2,218 yang artinya kecenderungan rumah tangga yang kepala kelurganya memiliki pendidikan tidak sekolah, SD atau SMP berpotensi menerima raskin 2,218 kali dari rumah tangga yang kepala keluarganya memiliki tingkat pendidikan SMA atau Perguruan Tinggi. Selain itu, nilai odd ratio untuk variabel $\mathrm{X}_{6}$ yaitu 2,782 yang artinya rumah tangga yang berjenis lantai tanah akan berpotensi menerima raskin 2,782 kalinya dibandingkan rumah tangga yang berjenis lantai rumah bukan tanah. Sementara itu, berdasarkan nilai odd ratio untuk variabel $\mathrm{X}_{10}$ yaitu 3,110 yang berarti bahwa rumah tangga yang memiliki pengeluaran untuk makan kurang dari 700.000 perbulan akan berpotensi menerima raskin 3,110 kalinya dibandingkan rumah tangga yang memiliki pengeluaran makanan lebih dari 700.000 per bulan.

3. Hasil interpretasi peluang menunjukkan bahwa rumah tangga yang kepala keluarganya memiliki pendidikan terakhir tidak sekolah/SD/SMP, memiliki jenis lantai rumah tanah, memiliki jenis bahan bakar bukan gas, pengeluaran untuk makan kurang dari 700.000 per bulan dan frekuensi membeli pakaian baru hanya 1 kali dalam setahun akan berpeluang menerima raskin sebesar 0,89 dan memiliki peluang tidak menerima raskin 0,11 .

\section{UCAPAN TERIMA KASIH}

Penulis mengucapkan terimakasih kepada pihak Kecamatan Langsa Barat yang telah memberikan izin kepada peneliti untuk melakukan survei hingga pengumpulan data sehingga sangat membantu dalam penyelesaian penelitian. Selain itu, penulis juga mengucapkan terima kasih kepada Dosen dan Mahasiswa Unsam yang ikut berpartisipasi dalam menyelesaikan penelitian.

\section{DAFTAR PUSTAKA}

[1] Y. Tampil, H. Komaliq, and Y. Langi, "Analisis Regresi Logistik Untuk Menentukan Faktor-Faktor Yang Mempengaruhi Indeks Prestasi Kumulatif (IPK) Mahasiswa FMIPA Universitas Sam Ratulangi Manado," d'CARTESIAN, vol. 6, no. 2, p. 56, 2017, doi: 10.35799/dc.6.2.2017.17023.

[2] T. Atika, "Evaluasi Pelaksanaan Program Beras untuk Keluarga Miskin di Kelurahan Tanjung Marulak Kecamatan Rambutan Kota Tebing Tinggi Evaluation of Implementation of Rice for Poor Family Program in Kelurahan Tanjung Marulak Rambutan Subdistrict ?? Tebing Tinggi,” J. Pemberdaya. Komunitas, vol. 14, no. 1, pp. 3-9, 2016.

[3] Y. Pujowati, "Implementasi Kebijakan Beras Miskin (RASKIN) DI Kecamatan Tanjunganom Kabupaten Nganjuk (Studi Deskriptif Pada Kelurahan Sumberkepuh),” Dialekt. J. Ekon. dan Ilmu Sos., vol. 2, no. 1, pp. 121-136, 2017, doi: 10.36636/dialektika.v2i1.237.

[4] I. Ramadhani, Faiz dan Zain, "Analisis Regresi Logistik Biner Untuk Mengindentifikasi Faktor-Faktor Yang Mempengaruhi Status Penerimaan Beras Keluarga Miskin (Raskin) di Kecamatan Gunung Anyar,” 2014.

[5] P. U. Raskin, Keputusan menteri koordinator bidang kesejahteraan rakyat nomor 54 tahun 2014. 2014.

[6] M. Hismawati and H. Hardiyan, "Pengambilan Keputusan Dalam Penerima Bantuan Raskin Dengan Metode Simple Additive Weigthing (SAW)," Swabumi, vol. 8, no. 1, pp. 74-77, 2018, doi: 10.31294/swabumi.v6i2.4557.

[7] C. Fadlan, S. Ningsih, and A. P. Windarto, "Penerapan Metode Naive Bayes Dalam Klasifikasi Kelayakan 
Keluarga Penerima Beras Rastra,” J. Tek. Inform. Musirawas, vol. 3, no. 1, pp. 1-8, 2018, doi: 10.32767/jutim.v3i1.286.

[8] H. Y. Safitri Daruyani, Yuciana Wilandari, "Faktor-faktor yang mempengaruhi indeks prestasi mahasiswa fsm universitas diponegoro semaster pertama dengan motode regresi logistik biner,” Pros. Semin. Nas. Stat., 2013.

[9] F. A. Novianti and S. W. Purnami, "Analisis Diagnosis Pasien Kanker Payudara Menggunakan Regresi Logistik dan Support Vector Machine (SVM) Berdasarkan Hasil Mamografi,” J. SAINS dan Seni ITS, 2012.

[10] S. Utomo, "Model Regresi Logistik Untuk Menunjukkan Pengaruh Pendapatan Per Kapita, Tingkat Pendidikan, dan Status Pekerjaan Terhadap Status Gizi Masyarakat Kota Surakarta,” 2009.

[11] G. Suwardika, "Pengelompokan Dan Klasifikasi Pada Data Hepatitis Dengan Menggunakan Support Vector Machine (SVM), Classification And Regression Tree (Cart) Dan Regresi Logistik Biner," J. Educ. Res. Eval., vol. 1, no. 3, pp. 183-191, 2017.

[12] D. W. Hosmer and S. Lemeshow, Applied Logistic Regression. 2000.

[13] I. Noviana et al., "Pemodelan Resiko Penyakit Pneumonia pada Balita di Jawa Timur Menggunakan Regresi Logistik Biner Stratifikasi,” J. SAINS DAN SENI POMITS, vol. 2, no. 2, pp. 225-230, 2015. 